\title{
EFFECT OF ETHANOL EXTRACT OF CHAYOTE ON THE ACTIVITY OF GLUTATHIONE PEROXIDE AND BLOOD SUGAR IN MICE WITH HYPERGLYCEMIA
}

\author{
Jekson Martiar Siahaan'1), Urip Harahap²), Ricke Loesnihari3) \\ 1) Department of Biomedical Science, Faculty of Medicine, \\ University of Sumatera Utara/Department of Physiology, \\ Faculty of Medicine, Methodist Indonesia University, Medan \\ 2) Faculty of Pharmacy, University of Sumatera Utara \\ 3) Faculty of Medicine, University of Sumatera Utara
}

\begin{abstract}
BACKGROUND: Streptozotocin (STZ) causes hyperglycemia in guinea pig through oxidative stress mechanism that damages pancreatic $\beta$ cells. Ethanol extract of chayote (Sechium edule Jacq. Swartz), locally called as "Ekstrak Etanol Buah Labu Siam" (EEBLS), was hypothesized to decrease oxidative stress. Glutathione peroxidase (GPx) is the general name of an enzyme family with peroxidase activity whose main biological role is to protect the organism from oxidative damage. This study aimed to determine the effect of EEBLS on decreasing blood sugar level and increasing the activity of GPx enzyme.

SUBJECT AND METHODS: This was a randomized controlled trial with before and after intervention outcome variable measurement. The study subjects were white male mice (Mus musculus L.) with DD Webster strain randomized into 4 groups: (1) Negative control group (normal); (2) Positive control group with STZ $60 \mathrm{mg} / \mathrm{kgBW}$; (3) Experimental group I with STZ $60 \mathrm{mg} / \mathrm{kgBW}$ and EEBLS of $100 \mathrm{mg} / \mathrm{kgBW}$; and (4) Experimental group II with STZ $60 \mathrm{mg} / \mathrm{kgBW}$ and EEBLS of $200 \mathrm{mg} / \mathrm{kgBW}$. The addition of STZ $60 \mathrm{mg} / \mathrm{kgBW}$ was intended to increase blood sugar level.
\end{abstract}

RESULTS: Blood sugar level $(\mathrm{mg} / \mathrm{dL})$ on the $28^{\text {th }}$ day in the negative control group was (mean $=127.67 ; \mathrm{SD}=12.93$ ), positive control group (mean=184.29; $\mathrm{SD}=21.24$ ), experimental group I (145.33; $\mathrm{SD}=11.13$ ), and experimental group II (mean=133.50; $\mathrm{SD}=38.19)$. EEBLS decreased blood sugar and it was statistically significant $(\mathrm{p}=0.001)$. The activity of GPx on the $28^{\text {th }}$ day in the negative control group was (mean $=420.05 ; \mathrm{SD}=78.95$ ), positive control group (mean $=425.98 ; \mathrm{SD}=22.50)$, experimental group I (mean $=427.57 ; \mathrm{SD}=73.82$ ), and experimental group II (mean=418.46; $\mathrm{SD}=54.90$ ). EEBLS did not increase the activity of GPx; the change in GPx was not statistically significant $(\mathrm{p}=0.992)$.

CONCLUSION: Ethanol extract of chayote (Sechium edule Jacq. Swartz) administered either in $100 \mathrm{mg} / \mathrm{kgBW}$ or $200 \mathrm{mg} / \mathrm{kgBW}$ decrease blood glucose level in mice, but does not increase the activity of glutathione peroxidase.

Keywords: blood glucose, glutathione peroxidase, ethanol extract of chayote 